\title{
Participatory design in the project of virtual learning environment of histology
}

\author{
José Guilherme Santa-Rosa \\ Rrt Department, (Laborazory of Usabizry experiments)، Federai Universiry of Rio Grande do Morte, Ry. Sen. Sazgado Filxo, \\ 3000، Universiry Campus، Lagoa noya, ZIP code 59078-970، Rn, Brasil.
}

\begin{abstract}
This present article describes a research on the development, under the approach of participatory design, a virtual teaching-learning of Histology in which students and teachers participated actively in all stages of development of the educational environment. We postulates that the development of virtual learning environment of Histology, through the Participatory Design approach, contributes to greater acceptance and use by students and that the adoption of virtual environment for teaching and learning by teachers is a determining factor of use by students.
\end{abstract}

Keywords: human-computer interaction, interfaces, development.

\section{InERODUCEION}

The Histology course (in which the tissues of living organisms are studied) is a mandatory subject required in several courses in biomedicine, such as Medicine, Pharmacy, Nursing, Physiotherapy. Among the main difficulties faced by students, we can mention issues of training and understanding of three-dimensional images from two-dimensional histological sections, the tissue classification and recognition of microscopic details and lack of awareness of students about the importance of basic sciences and more specifically, the histology for the training of health professionals [1].

\subsection{Lreraure review}

Since the 60s, several educational resources have been used to contribute to the teaching and learning relation of this course. Among them, we can mention the paper atlases, slides, videos and multimedia applications in video disks, CD-ROMs, DVDs and the Web, however, it has been realized that, in general, students have not adopted these tools to supplement their studies, although surveys have shown that replacing traditional resources by computerized ones do not compromise the learning [2].

By analyzing the main computer resources used in teaching and learning of Histology, it was noticed problems of usability, navigation and information architecture which contribute to the discontinuity of resource use and abandonment by the students.

This present article describes a research on the development, under the approach of participatory design (Muller et. al., 2003; Shneiderman, 1998), a virtual teaching-learning of Histology (Santa Rosa, 2010), in which students and teachers participated actively in all stages of development of the educational environment.

H1) The development of virtual learning environment of Histology, through the Participatory Design approach, contributes to greater acceptance and use by students. H2) The adoption of virtual environment for teaching and learning by teachers is a determining factor of use by students.

\section{MetrodoLOGY}

This present article describes a research on the development, under the approach of participatory design [3,6], a virtual teaching-learning of Histology [5] in which students and teachers participated actively in all stages of development of the educational environment. 
2.1 Phase 1: Evaluation of Virtual Environments for Teaching Histology - cooperative evaluation, heuristic evaluation [4,5].

To identify key educational issues such as difficulties, image interpretation, classification of tissues and structures as well as co-relation between form and function, limited time for study, and poor access to microscopes, understanding the importance of histology in the future professional practice of students were held and a survey of the theoretical and the state of the art, interviews, focus groups, usability tests and contextual observations, with teachers, students, the department monitors and specialists.

It was found that despite the willingness of students to new technologies, the manner in which the content of the discipline is organized and presented to existing systems, in most cases, is use of such systems.

It was found, in evaluations of existing problems of usability, information architecture and terminology inappropriate for audience of students, which leads us to conclude that probably, the systems are usually developed without considering the user as the centerpiece of development.

\subsection{Phase 2: Prototype Design of Virtual Learn-} ing Environment (using methods and techniques of Participatory Design)

Participatory design techniques such as cardsorting [figure 1], brainstorming and prototyping were used to define system requirements, information architecture, layout and graphical appearance of the interfaces and interaction model in order to adapt the built environment in a participatory needs As a result, it was realized that more than half of the class enrolled in the system and those most believe that the system has contributed to the learning of Histology.

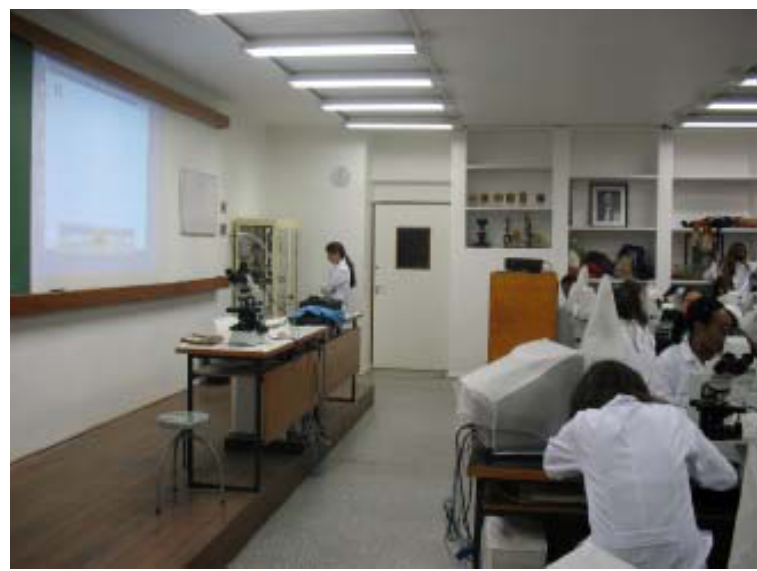

Figure 1. Cadsorting with sudents

2.4 Phase 3: Evaluation of the Virtual Prototype Environment

Even the students who have not signed up, many stated that the system will allow further consultation and review of discipline in the earliest stages of the course. It was noted, however, that most students used in the week of examinations, and although possible, no inserted their own micrographs, which indicates the consultative use of the virtual environment.

\subsection{Phase 4: Monitoring of the adoption of the} Virtual Environment

Regarding the environment developed in this research, it is worthwhile to mention that despite of all the students' participation during the phases of design and development, after the publication of the web environment, we noticed a low frequency of use, which refutes the hypothesis $\mathrm{H} 1$.
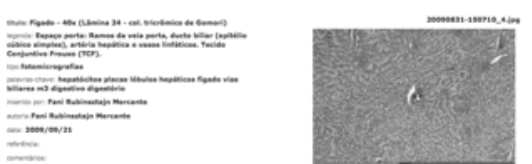

Figure 2. Histoexplorer's Interface 
It is noteworthy however that, from the time that teachers began to adopt the environment as a teaching tool in the classroom [figure 3], a significant increase in extra-study through the learning environment developed, confirming hypothesis 2 which states that the adoption virtual environment by teachers is a determining factor of use by students.

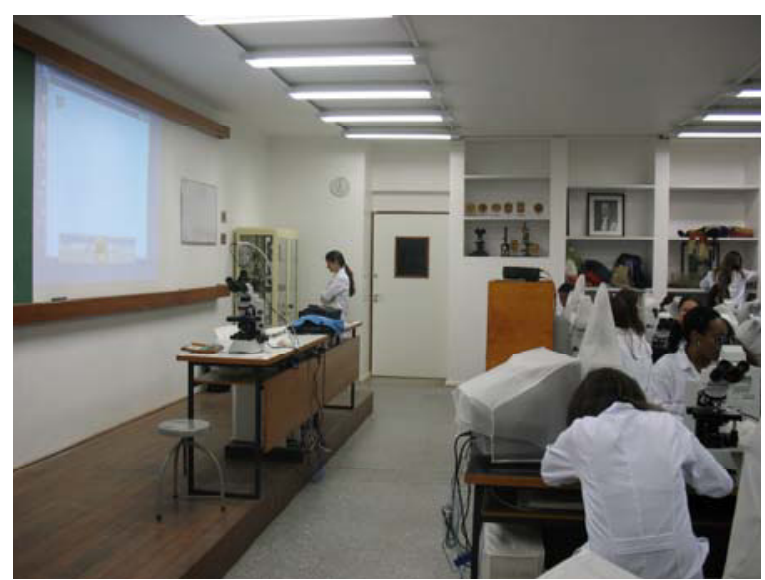

Figure 3. Began to adopt the environment as teaching tool in the classroom.

\section{Conciusion}

The study of the characteristics, capabilities, concerns and competences of older adults, is a valuable starting point to understand the usability problems that the elderly face, not to mention it can lead us to a more age-friendly work environment. However more recommendations still need to be studied and more tests have to be done, until the decrease of human capacities can be compensated by technology.
It was concluded that the virtual environments for teaching and learning should not be built only from the need to reduce costs and teaching materials available hourly load reduction for the course. The learning objectives must be clearly established and the needs and characteristics of students must be mapped. We conclude that include students and teachers in the development process of the learning environment is essential, however, the paper highlights the importance that teachers reflect on their strategies of adoption of environment. So, the students could build knowledge from student-teacher and student-student interactions.

\section{References}

[1] A.D. Fisk, Designing for older adults: Principles and creative human factors approaches.(2004), pp.97,108,148.

[2] [2] Garven, U.S.D. A Student's Histology, Livingstone: Edinburgh, 1957.

[3] Heidger, P.M, JR, Dee, F., Consor, D., Leaven, T., Duncan, J e Kreiter, C. Integrated Approach to Teaching and Testing in Histology With Real and Virtua Imaging. The Anatomical Record, 269: 107-112, 2002.

[4] Muller, M. J., Wildman, D. M. and White, E. Taxonomy of PD Practices: A Brief Practitioner's Guide. Communications of the ACM, 36(4), June 1993.Massachusetts, 1993.

[5] Santa Rosa, J.G e Moraes, A. Projeto e Avaliação no Design de Interfaces. Editora 2ab: Rio de Janeiro, 2010.

[6] Shneiderman, B. Desiging the user interface: strategies for effective human-computer interaction. 3rd. ed. - Reading, Mass: Addison-Wesley, 1998. 